\title{
New consumers: The influence of affluence on the environment
}

\author{
Norman Myers* ${ }^{\star \dagger}$ and Jennifer Kent ${ }^{\ddagger}$ \\ *Green College, Oxford University, Upper Meadow, Douglas Downes Close, Headington, Oxford OX3 8NT, United Kingdom; and ₹35 Dorchester Close, \\ Headington, Oxford OX3 8SS, United Kingdom
}

Contributed by Norman Myers, December 31, 2002

Growing consumption can cause major environmental damage. This is becoming specially significant through the emergence of over 1 billion new consumers, people in 17 developing and three transition countries with an aggregate spending capacity, in purchasing power parity terms, to match that of the U.S. Two of their consumption activities have sizeable environmental impacts. First is a diet based strongly on meat, which, because it is increasingly raised in part on grain, puts pressure on limited irrigation water and international grain supplies. Second, these new consumers possess over one-fifth of the world's cars, a proportion that is rising rapidly. Global $\mathrm{CO}_{2}$ emissions from motor vehicles, of which cars make up $74 \%$, increased during $1990-1997$ by $26 \%$ and at a rate four times greater than the growth of $\mathrm{CO}_{2}$ emissions overall. It is in the self-interest of new consumer countries, and of the global community, to restrict the environmental impacts of consumption; this restriction is achievable through a number of policy initiatives.

ncreasing consumption and especially its environmental impacts (1-5) are becoming all the more important now that the 850 million long-established consumers in rich countries have recently been joined by almost 1.1 billion new consumers in 17 developing and three transition countries. Most of these new consumers are far from possessing the spending capacity of the long-established consumers, but they have enough aggregate spending capacity, in terms of purchasing power parity (PPP), to match that of the U.S. Their numbers, consumption activities, and environmental impact are rising fast.

Of course, the new consumers should benefit from their affluence. This is a given, especially in light of the meager lifestyles that many of them have earlier experienced and the far greater consumption of long-affluent countries. But the environmental consequences of this new affluence are so significant that it will be in the self-interest of the 20 countries to restrict the damage with its economic penalties. In addition, and because of the global reach of certain environmental impacts, e.g., the $\mathrm{CO}_{2}$ emissions from cars that accelerate climate change, the entire world community has an interest in the emergent phenomenon of the new consumers, on top of its even greater stake in long-established consumers with their far more pronounced environmental impacts. The world community also has an interest in those 1.3 billion people who endure abject poverty and whose basic needs demand far greater consumption forthwith. Their needs, however vital and urgent, lie outside the scope of this paper.

\section{Who Are the New Consumers?}

We define new consumers as people within typically fourmember households with purchasing power of at least PPP $\$ 10,000$ per year, i.e., at least PPP $\$ 2,500$ per person, measured in PPP rather than conventional (international exchange) dollars (PPP dollars are between 1.3 and 5.3 times higher than conventional dollars in the 20 countries). From here on, we speak only of individual consumers, virtually all of whom possess purchasing power far above PPP \$2,500. The PPP dollar levels themselves appear to mark a degree of affluence that enables wide-ranging purchases such as household appliances and televisions, air conditioners, personal computers, and other consumer electronics, among other perceived perquisites of an affluent lifestyle. More significantly for environmental purposes, many new consumers enjoy a strongly meat-based diet and buy cars.

The calculations reflect an analytic model by using data on country populations, economic growth, PPP equivalents, income distribution, and consumption patterns $(6,7)$. The model reveals percentiles of populations at various income levels for the year 2000. The data for this purpose, as for other calculations, have been drawn largely from $>600$ articles and books in the peerreviewed literature and from reports and other documents of the World Bank/International Monetary Fund and the United Nations, among other leading agencies (see Supporting References, which is published as supporting information on the PNAS web site, www.pnas.org). We believe these are the most reliable information sources available on a singularly wide-ranging issue and recognize that not all data may be as authoritative as one might wish. But the degree of credibility must be balanced against the need to address an emergent phenomenon that has exceptional significance for the world's environmental and economic future alike.

There are sizeable numbers of new consumers in 20 selected countries with records of strong economic growth and populations of at least 20 million people (Tables 1 and 2). They comprise 17 developing and three transition countries. Among them are four countries, South Korea, Mexico, Turkey, and Poland, that are members of the Organisation for Economic Cooperation and Development (OECD), the "rich nations club," even though their per-capita gross national products are far below that of 23 high-income members. They are generally listed in OECD, World Bank, and United Nations documents as "middle income" or "upper middle income" countries as opposed to "high income" countries, hence they are included here as developing or transition countries.

In 14 countries, new consumers make up $12-56 \%$ of the population, and in six countries they make up $61-96 \%$. The new consumers' incomes are far greater than national averages because of income skewedness, a factor that applies in all 20 countries. In 16 countries, the top $20 \%$ of the population enjoy $\approx 50 \%$ or more of national income and in all 20 countries, $40 \%$ enjoy $62 \%$ or more (Table 2). In addition, the top quintiles generally show an increasing concentration of affluence and hence of consumption $(6,8)$.

New consumers have a far-reaching impact on economic activities nationwide, and hence on environmental repercussions. In India, for example, they accounted for less than one-eighth of the year 2000 population but two-fifths of the country's purchasing power (Table 1 ). With respect to the major sector of transportation, primarily cars, they accounted in the late 1990 s for $85 \%$ of private spending. Their per-capita energy consumption has been causing $\mathrm{CO}_{2}$ emissions 15 times greater than those of the rest of India's population (9).

Abbreviation: PPP, purchasing power parity.

†To whom correspondence should be addressed. E-mail: myers1n@aol.com. 
Table 1. New consumers, 2000

\begin{tabular}{|c|c|c|c|}
\hline Country & $\begin{array}{l}\text { Population, } \\
\text { millions, } 2000\end{array}$ & $\begin{array}{l}\text { New consumers, } \\
\text { millions, } 2000 \\
\text { (and percent of } \\
\text { population) }\end{array}$ & $\begin{array}{l}\text { Purchasing power, } \\
\text { PPP \$ billions } \\
\text { (and percent of } \\
\text { national total)* }\end{array}$ \\
\hline China & 1,262 & 303 (24) & $1,267(52)$ \\
\hline India & 1,016 & 132 (13) & 609 (39) \\
\hline South Korea & 47 & $45(96)$ & 502 (99) \\
\hline Philippines & 76 & $33(43)$ & $150(75)$ \\
\hline Indonesia & 210 & $63(30)$ & $288(56)$ \\
\hline Malaysia & 23 & $12(53)$ & $79(84)$ \\
\hline Thailand & 61 & $32(53)$ & $179(79)$ \\
\hline Pakistan & 138 & $17(12)$ & $62(31)$ \\
\hline Iran & 64 & $27(42)$ & $136(71)$ \\
\hline Saudi Arabia & 21 & $13(61)$ & 78 (87) \\
\hline South Africa & 43 & $17(40)$ & $202(83)$ \\
\hline Brazil & 170 & $74(44)$ & $641(83)$ \\
\hline Argentina $^{\dagger}$ & 37 & $31(84)$ & 314 (97) \\
\hline Venezuela & 24 & $13(56)$ & $87(86)$ \\
\hline Colombia & 42 & $19(45)$ & $136(83)$ \\
\hline Mexico & 98 & 68 (69) & $624(93)$ \\
\hline Turkey & 65 & $45(69)$ & $265(85)$ \\
\hline Poland & 39 & $34(86)$ & 206 (95) \\
\hline Ukraine & 50 & $12(23)$ & $44(45)$ \\
\hline Russia & 146 & $68(47)$ & $436(79)$ \\
\hline Totals & 3,632 & 1,059 (29) & $6,305(67)^{\ddagger}$ \\
\hline
\end{tabular}

*Equates to household consumption.

${ }^{\dagger}$ Argentina's figures do not reflect the recent economic recession.

${ }^{\ddagger}$ Comparable to the U.S. (6).

Finally, the new consumers started to emerge in significant numbers only in the early 1980 s, and their major increase in numbers occurred largely during the 1990s. True, there were some new consumers before the 1980s in countries such as Saudi Arabia, South Africa, Argentina, Brazil, and Mexico, but collectively they were generally few relative to the 2000 total.

\section{Two Predominant Sectors}

Meat. New consumers' diets are shifting toward meat, much of it raised in part on grain (Table 3). Raising $1 \mathrm{~kg}$ of beef can use 8 $\mathrm{kg}$ of grain, $4 \mathrm{~kg}$ of pork, and $2 \mathrm{~kg}$ of poultry (10). During the period 1990-2000 the amount of grain fed to livestock increased by $31 \%$ in China, $52 \%$ in Malaysia, and $63 \%$ in Indonesia. In nine of the 20 countries, two-fifths or more of grain consumed is now used for livestock (11), and the dietary change often leads to overloading of grainlands with resultant soil erosion and other forms of land degradation $(12,13)$. In addition, the 20 countries already account for nearly two-fifths of the world's grain imports; eight countries import one-fifth or more of their grain supply. In 2000, Malaysia imported $76 \%$ of its supply while feeding $41 \%$ to livestock, Saudi Arabia $78 \%$ and $65 \%$, South Korea $75 \%$ and $44 \%$, and Colombia $53 \%$ and $30 \%$ (Table 3 ). These imports serve to put pressure on international grain markets, to the detriment of poor countries that can hardly afford rising prices. Between 1997 and 2020, developing countries as a whole are forecast to increase their demand for meat, the great bulk to serve new consumers, by $92 \%$, for grain by $50 \%$, for food grain by $39 \%$, and for feed grain by $85 \%$ (14).

Furthermore, demand for increased grain harvests aggravates water shortages. To produce 1 tonne $\left(1\right.$ tonne $=10^{3} \mathrm{~kg}$ ) of grain can take 1,000 tonnes of water (15). Several sectors of China, a country with $29 \%$ of new consumers, experience water shortages, accentuated in part by the surging demand for grain. The North China Plain harbors two-fifths of the country's population and produces two-fifths of its grain but contains only one-fifth of its surface water. The region's aquifers have long been declining through overpumping by at least $1 \mathrm{~m}$ per year (16). In India, with $13 \%$ of new consumers, one-quarter of the grain

Table 2. Economic factors

\begin{tabular}{|c|c|c|c|c|c|c|}
\hline Country & $\begin{array}{l}\text { Conversion } \\
\text { \$/PPP\$ }\end{array}$ & $\begin{array}{l}\text { Purchasing power, } \\
2000 \text {, PPP \$billions* }\end{array}$ & $\begin{array}{l}\text { Income, top } \\
40 \% \text { share }\end{array}$ & $\begin{array}{l}\text { GDP growth, } \\
\% \text { 1990-1999 }\end{array}$ & $\begin{array}{c}\text { Household } \\
\text { consumption } \\
\text { growth, \%, 1990-1999 }\end{array}$ & $\begin{array}{c}\text { Household } \\
\text { consumption } \\
\text { growth, } \%, 2000\end{array}$ \\
\hline China & 4.67 & 2,434 & 69 & 10.7 & 8.8 & 6.3 \\
\hline India & 5.20 & 1,554 & 65 & 6.1 & 4.9 & 4.2 \\
\hline South Korea & 1.94 & 508 & 62 & 5.7 & 5.1 & 7.9 \\
\hline Philippines & 4.06 & 199 & 73 & 3.2 & 3.7 & 3.1 \\
\hline Indonesia & 4.96 & 511 & 66 & 4.7 & 6.2 & 3.6 \\
\hline Malaysia & 2.46 & 94 & 74 & 6.3 & 5.4 & 12.2 \\
\hline Thailand & 3.16 & 226 & 70 & 4.7 & 4.2 & 4.5 \\
\hline Pakistan & 4.23 & 201 & 62 & 4.0 & 5.1 & 0.9 \\
\hline Iran & 3.52 & 191 & $70^{+}$ & 3.4 & 2.9 & 6.9 \\
\hline Saudi Arabia & 1.58 & 90 & $72^{+}$ & 1.6 & $\mathrm{n} / \mathrm{a}$ & $\mathrm{n} / \mathrm{a}$ \\
\hline South Africa & 3.03 & 243 & 83 & 1.9 & 2.6 & 3.2 \\
\hline Brazil & 2.04 & 760 & 82 & 2.9 & 4.3 & 9.9 \\
\hline Argentina & 1.61 & 325 & 72 & 4.9 & 3.3 & 1.3 \\
\hline Venezuela & 1.33 & 101 & 74 & 1.7 & 0.4 & 3.7 \\
\hline Colombia & 3.00 & 164 & 79 & 3.2 & 3.0 & 6.5 \\
\hline Mexico & 1.73 & 671 & 77 & 2.7 & 1.9 & 8.3 \\
\hline Turkey & 2.27 & 312 & 69 & 4.1 & 3.7 & 6.2 \\
\hline Poland & 2.15 & 217 & 63 & 4.7 & 5.2 & 4.9 \\
\hline Ukraine & 5.29 & 98 & 63 & -10.8 & -8.0 & 5.2 \\
\hline Russia & 4.83 & 553 & 74 & -6.1 & 1.5 & 19.2 \\
\hline U.S. & 0.00 & $6,269^{\neq}$ & 69 & 3.4 & 3.2 & 5.6 \\
\hline World & 1.43 & $26,914^{\ddagger}$ & - & 2.5 & 2.6 & 3.6 \\
\hline
\end{tabular}

$\mathrm{n} / \mathrm{a}$, not applicable.

*Equates to household consumption.

${ }^{\dagger}$ Estimates.

${ }^{\ddagger}$ Latest data (6). 
Table 3. Meat

\begin{tabular}{|c|c|c|c|c|c|}
\hline Country & $\begin{array}{c}\text { Meat, kg } \\
\text { per capita, } 2000\end{array}$ & $\begin{array}{l}\text { Food grain, kg } \\
\text { per capita increase, } \\
1990-2000, \%\end{array}$ & $\begin{array}{c}\text { Feed grain, kg } \\
\text { per capita increase, } \\
1990-2000\end{array}$ & $\begin{array}{c}\text { Feed grain } \\
\text { as } \% \text { of } \\
\text { total grain, } 2000\end{array}$ & $\begin{array}{c}\text { Grain imports } \\
\text { as \% of } \\
\text { total grain, 200c }\end{array}$ \\
\hline China & 50 & -9 & 20 & 23 & 3 \\
\hline India & 5 & 2 & 0 & 1 & $<0.1$ \\
\hline South Korea & 46 & -7 & 36 & 44 & 75 \\
\hline Philippines & 27 & -6 & 14 & 28 & 14 \\
\hline Indonesia & 8 & 11 & 50 & 4 & 14 \\
\hline Malaysia & 51 & 19 & 22 & 41 & 76 \\
\hline Thailand & 24 & 11 & 11 & 34 & 9 \\
\hline Pakistan & 12 & 5 & 33 & 4 & 4 \\
\hline Iran & 22 & 3 & 10 & 32 & 44 \\
\hline Saudi Arabia & 51 & -7 & 84 & 65 & 78 \\
\hline South Africa & 39 & -1 & -4 & 32 & 14 \\
\hline Brazil & 77 & -3 & 44 & 54 & 21 \\
\hline Argentina & 98 & -1 & 28 & 44 & 1 \\
\hline Venezuela & 42 & -9 & -31 & 18 & 68 \\
\hline Colombia & 34 & 15 & 47 & 30 & 53 \\
\hline Mexico & 56 & 1 & 8 & 41 & 36 \\
\hline Turkey & 20 & -6 & 3 & 25 & 9 \\
\hline Poland & 70 & 6 & -23 & 58 & 9 \\
\hline Ukraine & 31 & -12 & -40 & 50 & 5 \\
\hline Russia & 40 & -6 & -44 & 48 & 9 \\
\hline U.S. & 122 & 5 & 1 & 66 & 3 \\
\hline World & 38 & -2 & -11 & 35 & - \\
\hline
\end{tabular}

See ref. 11.

harvest could be put at risk through groundwater depletion in its main breadbasket areas (17).

Cars. New consumers possess virtually all their countries' cars, and in most of the 20 countries, car totals have been expanding much more rapidly than national incomes. In 1990, these countries had 62 million cars, a total that by 2000 soared to 117 million or $21 \%$ of the global fleet (Table 4) (6). This $89 \%$ increase was led by China's $445 \%$, South Korea's 319\%, India's 259\%, and Colombia's $217 \%$. Five other countries registered increases of $100 \%$ or more, although the average annual increase for all 20 countries was only $6.4 \%$. In particular, China and India, being the two countries with largest new consumer totals, registered average annual increases of $19 \%$ and $14 \%$, respectively. Both these countries plan to push ahead vigorously with the "motorization" of their transport systems.

Allowing for growth in the proportionate numbers of people joining the affluent classes, the present decade could well see an average annual increase in car numbers at least matching the $6.4 \%$ rate of the $1990 \mathrm{~s}$. That would mean a total of at least 215 million cars in 2010, or one-quarter of the expected global fleet. Were the average annual increase to reach $10 \%$ due to disproportionately growing affluence on the part of new consumers both present and prospective, the 2010 total would approach 300 million, around one-third of the global fleet.

In 1997 the world's motor vehicles, of which 525 million, 74\%, were passenger cars, emitted $73 \%$ of transport-related $\mathrm{CO}_{2}$, for a 26\% increase over 1990 and four times more than the $\mathrm{CO}_{2}$ emissions increase overall. Cars are expected to make up the fastest-growing sector of energy use as far ahead as $2025(18,19)$.

Cars cause other forms of pollution such as urban smog and acid rain. They generate many other economic and social costs, notably road congestion, traffic accidents, and costly land use. In many cities of new consumer countries, road congestion is already acute and growing rapidly worse (20). In Bangkok, for instance, there are long periods every day when traffic moves at an average speed of just $3 \mathrm{~km}$ per hour. The problem has been costing an annual $\$ 1.6$ billion of fuel wasted in idling car engines and at least $\$ 2.3$ billion in lost worker productivity (21). Similar findings apply in Manila, Jakarta, and New Delhi, among other cities.

In addition to meat and cars, other new consumer purchases have harmful environmental impacts. A notable instance is

Table 4. Cars, millions

\begin{tabular}{|c|c|c|c|}
\hline Country & 1990 & $\begin{array}{c}2000 \\
\text { estimate }\end{array}$ & $\begin{array}{c}\text { Percent change } \\
1990-2000\end{array}$ \\
\hline China & 1.1 & 6.0 & 445 \\
\hline India & 1.7 & 6.1 & 259 \\
\hline South Korea & 2.1 & 8.8 & 319 \\
\hline Philippines & 0.4 & 0.8 & 100 \\
\hline Indonesia & 1.3 & 2.9 & 123 \\
\hline Malaysia & 1.8 & 4.1 & 128 \\
\hline Thailand & 0.8 & 1.9 & 138 \\
\hline Pakistan & 0.5 & 0.8 & 60 \\
\hline Iran & 1.4 & 2.1 & 50 \\
\hline Saudi Arabia & 1.6 & 1.9 & 19 \\
\hline South Africa & 3.4 & 4.1 & 21 \\
\hline Brazil & 11.8 & 18.5 & 57 \\
\hline Argentina & 4.4 & 5.5 & 25 \\
\hline Venezuela & 1.5 & 1.8 & 20 \\
\hline Colombia & 0.6 & 1.9 & 217 \\
\hline Mexico & 6.8 & 10.4 & 53 \\
\hline Turkey & 1.9 & 4.5 & 137 \\
\hline Poland & 5.3 & 9.9 & 87 \\
\hline Ukraine & 3.3 & 5.5 & 67 \\
\hline Russia & 10.1 & 19.5 & 93 \\
\hline Totals & 62.0 & 117.0 & 89 \\
\hline Percent of world & 13 & 21 & 62 \\
\hline U.S. & 152 & $175^{*}$ & 15 \\
\hline World & 478 & 560 & \\
\hline
\end{tabular}

*Including sport utility vehicles (SUVs) (6). 
electricity (generally derived from fossil fuels), which new consumers use at far above country-wide rates because of household appliances, air conditioners, and the like. The issue is not included in this article, because it is too difficult to pin down the amount used by new consumers, and because household electricity is not so environmentally significant as meat and cars.

\section{Two Country Case Studies}

In 2000, China had an estimated 303 million new consumers and India, 132 million, or two-fifths of the 20 countries' total. Let us look at these two countries in detail.

China. Not only does China possess the most new consumers today, but it offers the greatest scope for generating more new consumers in the future. During 1978-1998, its economic growth doubled per-capita income every 7 yr [compare South Korea at the height of its economic boom (11 yr) and Japan (34 yr)] (22). In 2000, China's gross national income [(GNI), a recent designation of the World Bank to replace gross national product (GNP)] totaled almost PPP \$5 trillion, making it the world's second largest economy in PPP terms (seventh largest in conventional dollars) (6).

China's new consumers are enjoying strongly meat-based diets. With one-fifth of the world's population, the country accounts for $28 \%$ of the world's meat consumption (compare to the U.S., $15 \%)(6,11)$, virtually all of it attributable to the new consumers. The 1990-2000 114\% increase in meat consumption accounted for 25 million tonnes or four-fifths of the country's $7 \%$ growth in grain consumption; today $23 \%$ of grain is fed to livestock, up from $19 \%$ in 1990. Although per-capita meat consumption almost doubled, and per-capita feed grain consumption grew by $20 \%$ during 1990-2000, per-capita food grain consumption declined by $9 \%$ (11).

As we have seen above, surging demand for grain is aggravating water deficits in the extensive North China Plain. In common with several other new consumer countries, China's grain imports effectively amount in part to water imports. Whatever China's water shortages today, they could become much more acute given that during 1997-2020 the country is forecast to account for $40 \%$ of the increased global demand for meat and $27 \%$ for grain (14).

China's new consumers are also buying cars in significant numbers. The total has grown from 1.1 million in 1990 to at least 6 million in 2000 (6). If the country maintains its 1990-2000 average annual growth rate of $19 \%$, it will have $\approx 34$ million cars by 2010 , an almost 6 -fold increase. If the additional new consumers expected to come on stream (300 million, see below) were to markedly increase the $19 \%$ rate, conceivably to as high as $25 \%(19,23,24)$, the 2010 total could be as much as 56 million cars.

How far will the new consumers increase beyond their 303 million in 2000? Let us suppose that during the present decade, the country's annual economic growth averages the forecast $7.0 \%$ (less than the $10 \%$ of the past two decades), meaning that the economy will more than double to PPP $\$ 9.7$ trillion $(6,7)$. Although many of the consumer benefits of the growing prosperity will accrue to the 303 million new consumers of 2000 , their total will surely swell by $6 \%$ per year (household consumption increases at a rate less than that of economic growth) to $\approx 543$ million in 2010. Because of income skewedness, however, which is likely to become yet more pronounced (25), the increasingly affluent new consumer class seems poised to forge still further ahead of the rest of the population, making for growth of their numbers more like $7 \%$ per year. Thus a more probable total in 2010 is $\approx 600$ million, or $44 \%$ of the projected population (compare to $24 \%$ in 2000). By then, their purchasing power could well climb to PPP $\$ 3.5$ trillion, or over half that of the U.S. today.

All this means that China's continued economic advance will have a marked impact on environments both national and global, and a good part of these impacts will reflect the rise of the new consumers $(26,27)$. During the 1990 s, environmental damage associated with economic growth (primarily air pollution and water deficits, but also deforestation and desertification) cost at least $8 \%$ and possibly $10-15 \%$ of gross domestic product, much of the damage being due to new consumers' activities $(26,28,29)$. Given China's economic globalization and the spread of Western lifestyles, a potential doubling of the new consumer total within the present decade is a formidable prospect when linked with shortages of grain and water, plus loss of farmland for industry, urbanization, and transport networks $(26,30)$.

The prospect is further challenging in terms of $\mathrm{CO}_{2}$ emissions (only a small proportion from cars but rising rapidly), which in 2000 placed China second to the U.S. with $49 \%$ as much, even though per capita they were only 2.2 tonnes per year by contrast with the U.S.'s 20.5 tonnes (31). Conversely, China has engaged in broad-scope policy reforms of its energy sector, resulting in a decline in $\mathrm{CO}_{2}$ emissions estimated at somewhere between $6 \%$ and 14\% during 1997-2000, although this decline applied far more to industry than to transportation (32-34).

India. India's economic growth rate has averaged $>6.0 \%$ per year during the 1990s, making its PPP \$2.4 trillion economy the fourth largest in the world (12th in conventional dollars) (6-8). The new consumer total in 2000 is estimated at 132 million (Table 1).

India's per-capita meat consumption is still meager, only one-tenth as much as China's (11), although still significant given the large number of new consumers who eat the great bulk of the country's meat. In absolute terms, however, and given that India has the second-highest number of new consumers, the country is the fourth-largest meat eater among all new consumer countries.

In 2000 , India's cars totaled $\approx 6.1$ million (Table 4 ), little more than in Greater Chicago, yet there were enough cars to cause much pollution of several sorts. Motor vehicles of all kinds account for $70 \%$ of air pollution, which has increased eight times during the past $20 \mathrm{yr}$, compared with a 4-fold increase for industry. Of the world's 10 cities with the highest air pollution, three are in India. The health costs of air pollution in 36 Indian cities have amounted to at least $\$ 500$ million per year and possibly four times as much (35). If the economy keeps expanding by at least $5.0 \%$ per year, car numbers can be expected to continue increasing by the annual $14 \%$ of $1990-2000$ on the grounds that, as in the past, the expanding consumer classes will become relatively more affluent than the rest of the population. This prognosis postulates a total of 23 million cars by 2010 .

Environmental damage of all kinds has been costing $\approx 5 \%$ of India' gross domestic product, due disproportionately to the activities of new consumers (36).

How many new consumers could there be by the end of this decade? An annual economic growth rate of $5.5 \%$ (reflecting the average for $1990-2000,6.1 \%$, and the expected growth rates for 2001-2003) means that India's economy will almost double to PPP \$4.1 trillion. As in the case of China, where household consumption does not increase as fast as economic growth, the new consumer total of 2000 is likely to grow by $1 \%$ less than the economy's expansion, namely $4.5 \%$ per year $(37,38)$. This will bring their numbers to $\approx 205$ million ( $18 \%$ of the projected population). In addition, income skewedness is likely to become more pronounced insofar as it is the top quintile that has benefited most from the country's economic advance of the past decade. So the new consumer total could readily soar by $5.5 \%$ per year to almost 225 million in 2010 or $19 \%$ of the population (compare to $13 \%$ in 2000). These new consumers would then have a purchasing power of > PPP \$1.2 trillion, putting them on a par with Germany today.

By 2010, then, China and India alone could feature 825 million 
new consumers with a purchasing power approaching PPP \$5.0 trillion (compare to the U.S. in 1999, $\$ 6.3$ trillion).

\section{Overview of 20 Countries}

All new consumers in the 20 countries totaled 1.059 billion in 2000 (Table 1). China and India accounted for $41 \%$ of the total. The third-largest total was Brazil with 74 million (7\%). Mexico and Russia had 68 million (6\%) each and Indonesia had 63 million $(6 \%)$. The smallest numbers were in Malaysia and Ukraine with 12 million (1\%) each, then Saudi Arabia and Venezuela with 13 million (1\%) each.

Equally revealing was the new consumers' share of each country's population. South Korea was top with $96 \%$; second was Poland with 86\%; and third, Argentina with $84 \%$ (the latter's figure will have dropped by today; see below). Lowest was Pakistan with $12 \%$, next India with $13 \%$, and then Ukraine with $23 \%$.

All of the 20 countries' totals in 2000 reflect the latest statistics of the World Bank and International Monetary Fund (6, 7). There have been recent economic downturns in a number of countries, most notably in Argentina. Argentina's new consumer total in 2000 was only 31 million, so a subsequent decline of, say, one-third to 21 million will make $<1.0 \%$ difference to the 20 countries' aggregate. No other country has registered such a severe and protracted economic decline (there have been transient dips in Saudi Arabia, Mexico, and Turkey), so no other new consumer totals will have dropped. As for the future, virtually all new consumer countries except Argentina are forecast to feature strong economic growth.

The overall purchasing power of the new consumers in 2000 amounted to PPP \$6.3 trillion, matching the U.S.'s (where PPP dollars and conventional dollars are the same by definition). In South Korea, overall purchasing power constituted $99 \%$ of the country-wide total. Next was Argentina with 97\% (although see qualifier above), followed by Poland with $95 \%$ and Mexico with 93\%. The lowest was Pakistan with $31 \%$, followed by India with $39 \%$ and Ukraine with $45 \%$ (Table 1 ).

Thus there is a sizeable "North" in the "South." The 2000 total of new consumers, approaching 1.1 billion, is to be compared with the collective populations of the 23 long-standing and much richer Organisation for Economic Cooperation and Development (OECD) countries, 850 million (6). True, the collective purchasing power of the new consumers, PPP $\$ 6.3$ trillion, contrasts with the 23 OECD countries' PPP \$15 trillion (6). All the same, the new consumers constitute a major consumer force in the global economy, just as they are becoming a front-rank factor in the global environment. China's environmental impact could eventually match that of the U.S.

An additional 14 countries, not considered here because their populations are $<20$ million or because their economies are not strong (or their data lacking), probably feature $\approx 140$ million new consumers, meaning their omission does not markedly affect the overall situation.

1. Daily, G. C. \& Ehrlich, P. R. (1996) Ecol. Appl. 6, 991-1001.

2. Holdren, J. P. (2000) Environment 42, 4-6.

3. Holdren, J. P. \& Ehrlich, P. R. (1974) Am. Sci. 62, 282-292.

4. Princen, T., Maniates, M. \& Conca, K., eds. (2002) Confronting Consumption (MIT Press, Cambridge, MA).

5. Stern, P. Dietz, T., Ruttan, V., Socolow, R. \& Sweeney, J., eds. (1997) Environmentally Significant Consumption: Research Directions (Natl. Acad. Press, Washington, DC).

6. The World Bank (2002) World Development Indicators Online, May 2002 (World Bank, Washington, DC).

7. International Monetary Fund (2002) World Economic Outlook April 2002 (International Monetary Fund, Washington, DC).

8. The World Bank (1994) World Development Report 1994 (Oxford Univ. Press, New York).

9. Consumers International (1998) A Discerning Middle Class? A Preliminary

\section{Policy Responses}

How can the new consumers be persuaded to reduce their environmental impacts and move toward sustainable consumption? Of course, the need to make consumption sustainable applies as well, only much more so, to the long-established consumers in the rich world, and the new consumers are unlikely to alter their consumption until the rich-world consumers take solid steps to modify their consumption.

Consider the scope for cleaner cars (39). A few recent models, notably the Toyota Prius and the Honda Insight, have hybrid engines that produce far less $\mathrm{CO}_{2}$ among other pollutants. Compressed natural gas powers $10 \%$ of Argentina's car fleet, and India has introduced the same fuel gas for heavy vehicles in its major cities. The prospective hydrogen fuel-cell car would emit only water vapor. In addition, there are many alternatives to the conventional car culture. Cities in developing country can promote mass transit systems, bicycle networks, and restrictions on cars in congested areas and can make drivers pay the full cost of their activity $(40,41)$. These diverse routes into the future are already illustrated by Singapore, Bogota, and the Brazilian city of Curitiba, in all of which fewer cars bring benefits all around (42-44).

As for meat, prices are often held down through large subsidies for grain and water (45). Consumers are induced to move up the food chain through dietary fads, taught taste, and social status, all of which can be shifted toward healthier diets through fiscal incentives such as a "food conversion efficiency" tax. The least-efficient converters of grain, notably beef, could be highly taxed, whereas more efficient products, notably poultry, could be moderately taxed (46). Similarly, there are many opportunities to foster more efficient use of water for the growing of grain (47). Use of other natural resources can be improved through full-cost pricing $(48,49)$, shifts in tax systems $(50,51)$, substitutes for gross national product as an economic indicator $(52,53)$, elimination of "perverse" subsidies that foster both environmental and economic inefficiencies (45), and application of the many ecotechnologies available (54-57).

Above all is the need to establish sustainable consumption as a norm, which is not only about quantitative reductions in our use of materials and energy (58-60); it is also about ways in which we can achieve an acceptable quality of life for all in perpetuity and exemplify it throughout our lifestyles (61). How, for instance, can we attain a better balance between work, leisure, and consumption $(63,64)$ ? How can we prevent yesterday's luxuries from becoming today's necessities and tomorrow's relics (65, $66)$ ? How can we make fashion sustainable and sustainability fashionable?

For many helpful comments on an early version of this article, we thank G. C. Daily and D. M. Pimentel. T. L. Root and S. H. Schneider of Stanford University provided an economic model used to determine income distribution within national populations. We gratefully acknowledge financial support for our original research from the Winslow Foundation (Washington, DC).

Enquiry of Sustainable Consumption Trends in Selected Countries in the Asia Pacific Region (Consumers International, Penang, Malaysia).

10. Smil, V. (2000) Feeding the World: A Challenge for the Twenty-First Century (MIT Press, Cambridge, MA).

11. Food and Agriculture Organization (2002) FAOSTAT Food Balance Sheets June 2002 (Food and Agriculture Organization, Rome).

12. World Resources Institute (1999) Critical Consumption Trends and Implications: Degrading Earth's Ecosystems (World Resources Institute, Washington, DC).

13. Tilman, D., Fargione, J., Wolff, B., D’Antonio, C., Dobson, A., Howarth, R., Schindler, D., Schlesinger, W. H., Simberloff, D. \& Swackhamer, D. (2001) Science 292, 281-284.

14. Rosegrant, M. W., Paisner, M. S., Meijer, S. \& Witcover, J. (2001) 2020 Global Food Outlook: Trends, Alternatives, Choices (International Food Policy Research Institute, Washington, DC). 
15. Gleick, P. (2000) The World's Water 2000-2001 (Island Press, Washington, DC).

16. Qingcheng, H. (2001) The North China Plain and Its Aquifers (Geological Environmental Monitoring Institute, Beijing, P.R. China).

17. Seckler, D., Molden, D. \& Barker, R. (1998) Water Scarcity in the Twenty-First Century (International Water Management Institute, Colombo, Sri Lanka).

18. International Energy Agency (2000) International Energy Outlook 2000 (International Energy Agency, Paris).

19. Schipper, L., Marie-Liliu, C. \& Lewis-Davis, G. (1999) Rapid Motorization in the Largest Countries in Asia: Implications for Oil, Carbon Dioxide and Transportation (International Energy Agency, Paris).

20. Willoughby, C. (2000) Managing Motorization (The World Bank, Washington, DC).

21. DuPont, P. \& Egan, K. (1997) World Transport and Policy Practice 3, 25-37.

22. The World Bank (1999) World Development Report, 1999 (Oxford Univ. Press, New York).

23. Schipper, L. (2001) Designing "Effective" Solutions to the Urban TransportEnvironment Dilemma (Organisation for Economic Cooperation and Development, Paris).

24. Riley, K. (2002) Popul. Environ. 23, 479-494.

25. Atinc, P. M. (1997) Sharing Rising Incomes: Disparities in China (The World Bank, Washington, DC).

26. The World Bank (2001) China Air, Land and Water: Environmental Priorities to a New Milennium (The World Bank, Washington, DC).

27. Palanivel, T. (2001) Sustainable Development of China, India and Indonesia: Trends and Responses (Institute of Advanced Studies, United Nations University, Tokyo).

28. Smil, V. \& Yushi, M. (1998) The Economic Costs of China's Environmental Degradation (Am. Acad. Arts and Sciences, Cambridge, MA).

29. Takahiro, A. \& Nakamura, Y. (2000) Green GDP Estimates in China, Indonesia and Japan (Institute for Advanced Studies, United Nations University, Tokyo).

30. Brown, L. R. (2001) Eco-Economy: Building an Economy for the Earth (Norton, New York).

31. Energy Information Administration, U.S. Department of Energy (2002) International Energy Database, April 2002 (U.S. Department of Energy, Washington, DC).

32. Natural Resources Defence Council (2001) Second Analysis Confirms Greenhouse Gas Reductions in China (Natural Resources Defense Council, Washington, DC).

33. Streets, D. G, Jiang, K., Hu, X., Sinton, J. E., Zhang, X. Q., Xu, D., Jacobson, M. Z. \& Hansen, J. E. (2001) Science 294, 1835-1837.

34. Sinton, J. E. \& Fridley, D. G. (2000) Environ. Pol. 28, 671-687.

35. Agarwal, A. \& Narain, S. (1997) Economic Globalisation: Its Impact on Consumption, Equity and Sustainability (Center for Science and the Environment, New Delhi, India).

36. Parikh, J. \& Parikh, K. (2001) Accounting for Environmental Degradation: A Case Study of India (Institute for Advanced Studies, United Nations University, Tokyo).

37. Alagh, Y. K. (2001) India's Sustainable Development Framework: 2020 (Institute for Advanced Studies, United Nations University, Tokyo).

38. Klein, L. R. \& Palanivel, T. (2000) Economic Reforms and Growth Prospects in India (Institute for Advanced Studies, United Nations University, Tokyo).
39. Motavalli, J. (2002) Forward Drive: The Race to Build Clean Cars for the Future (Earthscan, London).

40. Satterthwaite, D., ed. (1999) Sustainable Cities (Earthscan, London).

41. Bose, R., Sperling, D., Tiwari, G. \& Schipper, L. (2001) Transportation in Developing Countries (Pew Center on Global Climate Change, Arlington, VA)

42. Newman, P. (1999) Automobile Dependence (Island Press, Washington, DC).

43. Rabinovitch, J. (1996) Land Use Pol. 13, 51-67.

44. Sheehan, M. (2001) City Limits: Putting the Brakes on Sprawl (Worldwatch Institute, Washington, DC).

45. Myers, N. \& Kent, J. (2001) Perverse Subsidies: How Tax Dollars Can Undercut the Environment and the Economy (Island Press, Washington, DC).

46. Pimentel, D., Westra, L. \& Noss, R. F. (2000) Ecological Integrity: Integrating Environment, Conservation, and Health (Island Press, Washington, DC).

47. Postel, S. (1999) Pillar of Sand: Can the Irrigation Miracle Last? (Norton, New York).

48. Pearce, D. \& Barbier, E. B. (2001) Blueprint for a Sustainable Economy (Earthscan, London).

49. Roodman, D. (1998) The Natural Wealth of Nations (Norton, New York).

50. Ekins, P. \& Speck, S. (2000) J. Environ. Pol. Plann. 2, 93-114.

51. Wallart, N. (1999) The Political Economy of Environmental Taxes (Edward Elgar, Cheltenham, U.K.).

52. Cobb, C., Goodman, G. S. \& Wackernagel, M. (1999) Why Bigger Isn't Better The Genuine Progress Indicator, 1999 Update (Redefining Progress, San Francisco).

53. Dasgupta, P. \& Maler, K.-G. (2000) Environ. Dev. Econ. 5, 69-93.

54. DeSimone, L. D. \& Popoff, F. (2000) Eco-Efficiency: The Business Link to Sustainable Development (MIT Press, Cambridge, MA).

55. Hawken, P., Lovins, A. B. \& Lovins, L. H. (1999) Natural Capitalism (Little, Brown, Boston).

56. Russel, T. (2001) Eco-Efficiency: A Management Guide (Earthscan, London).

57. McDonough, W. \& Braungart, M. (2002) Cradle to Cradle: Remaking the Way We Make Things (North Point Press, New York).

58. Arrow, K., Daily, G., Dasgupta, P., Ehrlich, P., Goulder, L., Heal, G., Levin, S., Maler, K.-G., Schneider, S., Starrett, D. \& Walker, B. (2003) J. Econ. Perspect., in press.

59. Pauli, G. (1998) Up Sizing: The Road to Zero Emissions (Greenleaf Publications, London).

60. Schmidt-Bleek, F. (2000) Factor 10 Manifesto (The Factor Ten Institute, Carnoules, France).

61. Frank, R. H. (1999) Luxury Fever: Why Money Fails to Satisfy in an Era of Excess (Free Press, New York).

62. Kates, R. W., Clark, W. C., Corell, R., Hall, J. M., Jaeger, C. C., Lowe, I., McCarthy, J. J., Schellnhuber, H. J., Bolin, B. \& Dickson, N. M. (2001) Science 292, 641-642.

63. Schor, J. B. (1998) The Overspent American: Upscaling, Downshifting, and the New Consumer (Basic Books, New York).

64. Kasser, T. (2002) The High Price of Materialism (MIT Press, Cambridge, MA).

65. Daly, H. E. (2000) Ecological Economics and the Ecology of Economics (Edward Elgar, Cheltenham, U.K.).

66. Robins, N. \& Roberts, S. (1998) Development (Cambridge, U.K.) 41, 28-36. 